\title{
Nursing students' perception of academic support in the practicum: Development of a reliable and valid measurement instrument
}

\author{
Juan Arribas-Marín ${ }^{\mathrm{a}, *}$, Vicente Hernández-Franco ${ }^{\mathrm{b}}$, Calixto Plumed-Moreno ${ }^{\mathrm{c}}$

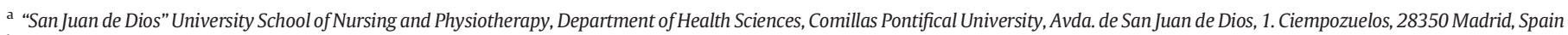 \\ ${ }^{b}$ Faculty of Humanities and Social Sciences, Department of Education, Research and Evaluation Methods, Comillas Pontifical University, C/Universidad Comillas, 3, 28049 Madrid, Spain

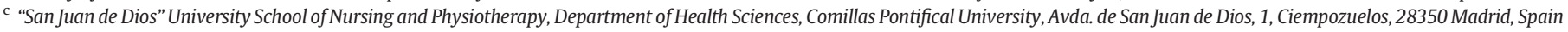

\section{A R T I C L E I N F O}

\section{Article history:}

Received 12 March 2016

Revised 26 January 2017

Accepted 17 March 2017

\section{Keywords:}

Clinical practice

Measurement scales

Nursing students

Psychometric properties

Structural model

Academic support

\begin{abstract}
A B S T R A C T
Background: The importance of practicum training in health sciences disciplines places prominence on the academic support received by students in this learning environment, both due to its leverage over their perceived level of satisfaction of academic proficiency as well as its impact on their academic performance.

Aim: The aim of this study was to develop and validate a scale which facilitates the evaluation of academic support perceived by nursing students during their practicum.

Participants: The sample is made up of 710 students from three academic levels of the Bachelor's Degree in Nursing.

Method: An instrument to evaluate the level of academic support perceived by the students was developed and validated. Subsequently, a measurement model of the dimensions which comprise the academic support in the practicum was created.

Results: The Academic Support in the Practicum Scale demonstrated high internal consistency, with a Cronbach's alpha value $=0.913$. The validation of the measurement instrument was carried out using confirmatory factor analysis and multi-sample analysis techniques, which presented positive goodness-of-fit indices.

Conclusions: The developed tool has shown sufficient validity and high internal consistency. Its adequate psychometric properties lead to the conclusion that the scale provides a reliable and valid measurement of academic support perceived by students during their placement.
\end{abstract}

(c) 2017 Elsevier Inc. All rights reserved.

\section{Introduction}

The importance of the practicum within the European Higher Education Area warrants the proposal of a new instrument that rates the academic support perceived by students in professional spaces where they carry out their placements. The practicum is integrated in the set of subjects comprising the curriculum, and it has been established as a focal and integrative component in training projects. Its structure aims to furnish the student with the resources to attain a certain professional, and thus, skilled, profile. This integration allows the practicum to enrich training, complementing academic training with experience in workplaces (Zabalza, 2006). This integrative perspective of training in professional contexts differs from any other approach which contemplates its course syllabus in a fragmentary and individual manner (González \& Hevia, 2011; Martínez \& Raposo, 2011; Rodicio \& Iglesias, 2011; Zabalza, 2011).

\footnotetext{
* Corresponding author.

E-mail addresses: juanmarribas@comillas.edu (J. Arribas-Marín), vhernandez@comillas.edu (V. Hernández-Franco),cplumed@comillas.edu (C. Plumed-Moreno).
}

Regarding this, nursing schools have incorporated specific frameworks to the practicum which have been defined as sources of academic support by encouraging adequate curricular development and adapting the student to professional learning environments. Savitz-Romer (2009) proposed that "Academic support typically refers to the formal and informal strategies that build, strengthen, and promote students' mastery of subject matter and skill development through deliberate activities, structures, policies, and expectations" (p. 6).

The level of academic support in the nursing practicum has effects on the students' perception of wellbeing, influences their academic performance, decreases levels of stress in the clinical learning environment (Graham, Lindo, Bryan, \& Weaver, 2016) and reduces attrition rates in nursing education (Eick, Williamson, \& Heath, 2012; Ujváriné et al., 2011). Therefrom emerges the need for in-depth analysis of the support provided by specific sources of the practicum (peers, preceptors, clinical facilitators and Academic Institution).

This study would help lay the bases for future actions which would improve the efficiency of tutoring and academic organization dynamics, needs shows at studies as Andrews et al. (2006), o reviews as Helminen, Coco, Johnson, Turunen, and Tossavainen (2016). 


\section{Background/literature review}

Research development about Academic Support construct has been traditionally vinculated with social support studies at school. This consideration was proposed by Lin, Dean, and Ensel (1986) who defined social support like "the perceived or actual instrumental and/or expressive provisions supplied bit he community, social networks, and confiding partners" (p. 9). Based on this, this definition, social support in the academic sphere would fall within the middle level or the immediate surroundings of the student per Gottlieb's theory on support networks (Gottlieb, 1981): macro or community level, regarding the community as an entity for integration and participation; meso or middle level, which takes account of social networks to which the individual belongs; and micro, which encompasses close relationships. This makes it possible to reflect on its connection with specific social networks in an academic context. Several articles and research projects have looked at the support determinants in the academic context (Arribas, 2013; Jones, 2008; Tao, Dong, Pratt, Hunsberger, \& Pancer, 2000; Wilkes \& Feldman, 2017). These pieces of research verified the importance students place on factors which determine the perception of support depending on various cultural, socio-economic variables and others inherent to this field such as the educational stage and academic level.

In this matter, Savitz-Romer says: "in practice, however, academic and social supports are interrelated, intertwined, and experienced simultaneously" (p. 9). And he develops an integrated definition of both types of support: "Academic and social support comprises intentional strategies that enable students at all levels to benefit from academically rigorous curricula. These strategies are interrelated, developmentally appropriate, and provide integrated, coordinated, and comprehensive support to improve student achievement" (p. 1).

However, Savitz-Romer proposal ask about the proper essence of Academic Support construct. Mazer and Thompson (2011b), Song, Bong, Lee, and Kim (2015), o Turkpour and Mehdinezhad (2016) shows how social and academic support are similar, but not the same. The Turkpour and Mehdinezhad (2016), study explored the relationships between social support, academic support and adaptation to college, showed discharge support (component of academic support) can predict students' adaptation to university, whereas in any case the components of social support can predict this adaptation. Mazer and Thompson (2011b) in their research about Student Academic Support Scale (SASS; Thompson \& Mazer, 2009validity, concludes: "offer evidence for discriminant validity and suggest that the SASS is distinct from traditional measures of social support. This finding is particularly noteworthy and further distinguishes the operationalization of academic support from traditional forms of social support" (p. 83). Finally, Song et al. (2015) lays out about academic and emotional support provided by parent and teachers although "correlated strongly with each other in his study/...they clearly formed two independent factors, as defined by their respective items" (p. 834). In this last study, Song et al. (2015) define perceived academic support as "the belief that significant others value and encourage student learning and progress by modeling, helping, and providing guidance and information when necessary" ( $p$. 823). This definition allows to categorize academic support in four ranks, proposed by House (1981): a) emotional (offers the individual empathy, trust and affection); b) informative (to provide information to help resolve problems or achieve goals); c) the tangible or instrumental (which provides material or temporary resources or services); and appraisal support (which provides communication or relevant information for the individual for his/her self-assessment).

These two visions of the academic support construct have supposed a development of heterogeneous instruments to evaluate academic support. These vary both in the evaluated support sources as well as in the support type provided, in order to be adapted to the specific characteristics of the academic levels subject of study or to age groups: the Student Perceptions of Classroom Support Scale (SPCS) by O'Rourke and Houghton (2006) measures the perception of students with mild impairments of social and academic support in the classroom; the Mature Student Social Support Scale (Wong \& Kwok, 1997) for adult college students, which includes study area support; the Child and Adolescent Social Support Scale (CASSS; Malecki, Demaray, \& Elliott, 2000) focuses on the child and adolescent stages, with five subscales (parent, teacher, friend, classmate and school). These resources include a related academic support items. Finally, one of the instruments specifically used to measure academic support for college students is the SASS (Thompson \& Mazer, 2009), evaluation of which concentrates on the frequency and importance of the support received by other college students and the type of support they provide (information, self-esteem, encouragement and expression of feelings).

In the review of the literature, one aspect that has not been assessed thus far is the academic support provided in the specific context of the practicum in health sciences disciplines.

Bearing this in mind, the need to design a reliable and valid measurement instrument to assess the perception of academic support of nursing students on their practicum is addressed. This general aim may be split into the following specific aims: a) explore the dimensionality of Academic Support in the Practicum construct, and b) analyze all possible factors which configure each dimensions of the scale.

The results of this study would create a operative definition about practicum academic support construct and help lay the bases for future actions which would improve the efficiency of tutoring and academic organization dynamics, needs shows at studies as Andrews et al. (2006), o reviews as Helminen et al. (2016).

\section{Method}

\section{Participants and procedure}

The Academic Support in the Practicum Scale (Escala de Apoyo Académico en el Prácticum in Spanish, EAPAP) was conducted on 710 undergraduate nursing students from six Spanish universities during two academic years. The development of the instrument was framed into a wellbeing determinants research in practicum nursing students. This project was presented in informative sessions to students. Online emplacement was showed, where students could answer the project questionaries' pack. The unique inclusion criteria were that the students were enrolled in practicum subject at their academic level. Participants were done a blind registration process and gave informed consent to include their data into a Hospitare Project file.

\section{Ethical considerations}

The study was assessed and approved by the Comillas Pontifical University Ethical Committee. Students voluntarily responded to questions via an online version of the EAPAP (it is offered on the Proyecto Hospitare digital portal: www.upcomillas.es/hospitare) after completing their practical training. Data collection gathered from students' replies were anonymous and they are protected under Spanish and European personal data laws.

Table 1

Second-order factor structure of the Academic Support in the Practicum Scale (EAPAP), $(N=710)$.

\begin{tabular}{ll}
\hline Academic support in the practicum & Component \\
\hline 1. Academic institution support & 0.771 \\
2. Clinical facilitator support & 0.758 \\
3. Peers support & 0.564 \\
4. Preceptor support & 0.548 \\
\hline
\end{tabular}

Extraction Method: Principal Component Analysis.

Rotation Method: Promax with Kaiser Normalization.

a) 1 component extracted. 
Table 2

Mean, SD, Cronbach's $\alpha$ and loading factor of the EAPAP. $(N=710)$.

\begin{tabular}{|c|c|c|c|c|c|c|c|}
\hline Practicum's academic support sources and support types & $\begin{array}{l}\text { Compc } \\
\text { D1 }\end{array}$ & D2 & D3 & D4 & $M$ & $\sigma$ & Cronbach's \\
\hline Clinical facilitator appraisal support & 0.984 & & & & 6.70 & 2.61 & $=0.925$ \\
\hline Clinical facilitator emotional support & 0.942 & & & & & & \\
\hline Preceptor information support & & 0.951 & & & 8.22 & 1.84 & $=0.856$ \\
\hline Preceptor appraisal support & & 0.926 & & & & & \\
\hline Peers emotional support & & & 0.923 & & 7.01 & 2.19 & $=0.761$ \\
\hline Peers information support & & & 0.881 & & & & \\
\hline Academic institution instrumental support & & & & 0.961 & 6.30 & 2.20 & $=0.754$ \\
\hline Academic institution emotional support & & & & 0.831 & & & \\
\hline
\end{tabular}

Extraction Method: Principal Component Analysis.

Rotation Method: Promax with Kaiser Normalization.

a. Rotation converged in 5 iterations.

The tools of procedures to obtain, process and communicate the data from this research were aligned according to the provisions set forth in Spanish and European legislation on personal data protection.

\section{Development of the instrument}

The proposal of items was carried by reviewing the theoretical foundation of the construct and of specific instruments to measure social support (Peterson, Peterson, Lowe, \& Nothwehr, 2009; Thompson \& Mazer, 2009; Zimet, Dahlem, Zimet, \& Farley, 1988). This was presented to three focus groups (students, experts and practicum tutors). The first prototype of the instrument was administered to 166 students from fourth and sixth semester. The reliability analysis and principal components factor analysis helped to select the most significant indicators that made up the pilot version of the EAPAP, on which Exploratory Factor Analysis (EFA) and Confirmatory Factor Analysis (CFA) techniques were used for its evaluation. An online version of the resulting prototype comprising 31 items was added to a digital platform to collect the information and incorporate it into a database for subsequent study. An 11-point Likert scale was chosen for this version, where 0 would equate to "never" and 10 to "always". For European samples "the use of items measured by an 11-point scale leads to composite scores with higher reliability and lower invalidity than the use of a 5point scale" (Batista-Foguet, Saris, Boyatzis, Guillén, \& Serlavós, 2009; p. 580). Based on the data analysis and results obtained, a reliability and validity study of the scale was conducted and developed by authors team.

\section{Analysis}

The evaluation of the measurement instrument was carried out at an initial stage using reliability analysis and EFA techniques. An estimate based on the polychoric correlation matrix was made to analyze the main components, which is considered the most adequate option (Flora \& Curran, 2004) considering the continuing nature of the scale's variables. Based on the dimensions obtained from the EFA and in keeping with the theoretical framework for the research, three models for CFA were proposed using Structural Equation Modeling (SEM). To check the goodness of fit and the validity of the models, the $\chi^{2}$ statistic and varying descriptive fit indices were used. Lastly, analysis of the model's invariance was carried out in the two cohorts of students using CFA multi-sample techniques. The IT program used for the EFA was SPSS Statistics for Windows version 20.0 (IBM Corporation, 2011. IBM SPSS Statistics for Windows, Version 20.0. Armonk, NY), and the Factor 9.2 program (Lorenzo-Seva \& Ferrando, 2013) in the polychoric correlation analysis. For the CFA of the model and the invariance analysis the EQS 6.2 program for Windows was used (Bentler \& Wu, 2012). The various goodness-of-fit indices and residuals were calculated using the maximum-likelihood estimation method (Bentler, 2006), which are less sensitive to the absence of multivariate normality (Mardia coefficient $>5$ ) presented by the distributions of obtained data.

\section{Results}

In the academic year 2012/13 responded a total of 450 students $(63,4 \%)$, and the academic year $2013 / 14$ a total of 260 students $(36,6 \%)$. The $53.7 \%$ of students were reported to be in the fourth semester of the nursing degree, $34.9 \%$ in the sixth semester and $11.4 \%$ in the eighth. The average age of participants was 23.73 years. Regarding age, 399 students $(56,2 \%)$ were between 19 and 22 years old (yo); 183 (25,8\%) 23-26 yo; 56 (7,9\%) 27-30 yo; an finally, 72 (10,1\%) were older than 31 years old. Regarding gender, 591 were female (83.2\%) and 119 male (16.8\%). Lastly, 182 students were employed during the academic year (25.6\%).

\section{Reliability and exploratory factor analysis (EFA)}

The EFA, which was carried out on the final prototype of the 31-item scale, discovered that the most significant indicators were grouped into four dimensions, thereby producing a 23-item scale (Appendix A) after selecting those which had the greatest weighting in each one of the factors without sharing appreciable weights in the others.

This scale presented a high internal consistency (Tang, Cui, \& Babenko, 2014), with a Cronbach's alpha coefficient $=0.919$. In the EFA of the scale, the Kaiser-Meyer-Olkin (KMO) "sampling adequacy" index displayed a value of 0.880 (close to one), and a significant Bartlett's test of sphericity $\left(\chi^{2}=16,178,15\right.$, d.f. $\left.=253, p<0.000\right)$. In the result obtained using the EFA based on the polychoric correlation matrix (weighted least squares method and Promax rotation), 4 factors were identified in the extraction which explained $74.77 \%$ of the variance total, presenting indicators with values higher than 0.695 for only one factor (Appendix B), and several adequate fit indices: Goodness-of-Fit Index $(\mathrm{GFI})=0.99$; Root Mean Square of Residuals (RMSR) $=0.0401$.

Table 3

Goodness-of-fit indicators for the hypothesized models $(N=710)$

\begin{tabular}{|c|c|c|c|c|c|c|}
\hline Model & Satorra-Bentler $\chi 2^{1}$ & $\mathrm{df}$ & NFI Robust & NNFI Robust & CFI Robust & RMSEA Robust \\
\hline Model 1: Four correlated second-order factors & 597.91 & 212 & 0.940 & 0.952 & 0.960 & $0.051(0.046,0.055)$ \\
\hline Model 2: Three correlated second-order factors & 786.65 & 216 & 0.921 & 0.931 & 0.941 & $0.061(0.056,0.066)$ \\
\hline Model 3: Single second-order factor & 1465.19 & 221 & 0.852 & 0.852 & 0.871 & $0.089(0.085,0.093)$ \\
\hline
\end{tabular}

${ }^{1} p<0.00000$. 
The four sub-scales displayed high internal consistency indices with alphas of between 0.88 and 0.96 . The homogeneity indices were also satisfactory, with item-total correlations higher than 0.66 for each indicator.

Based on these results, the resulting latent variables were made operative in line with the observable variables. This helped to confirm that the Academic Support in the Practicum construct may be structurally configured into four components or dimensions: a) Clinical facilitator Support; b) Preceptor Support; c) Academic Institution Support; and d) Peers Support. All the deriving factors had significant inter-correlations. A second-order EFA demonstrated that the factors presented a one-dimensional factor structure (Table 1). As a result, a second-order

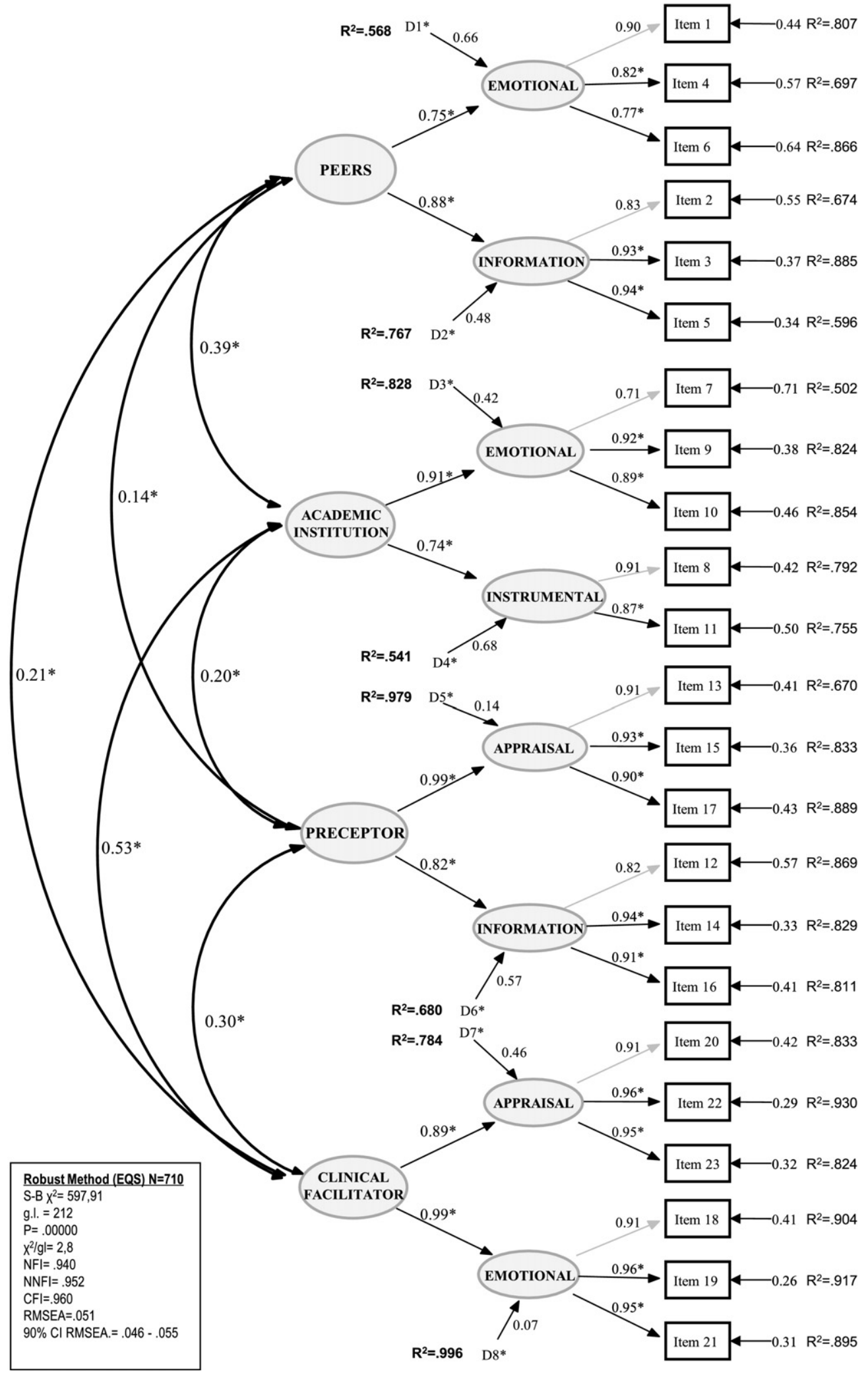

Fig. 1. Standardized parameter estimates for the measurement model of the EAPAP. Model 1 (4 correlated second-order factors), $(N=710)$. 
factor was obtained as a factorial summary of the twenty-three indicators, which explained the $44.7 \%$ variance, and which was theoretically interpreted as the "Academic Support in the Practicum". Therefore, the practicum academic support construct can be operationally defined as: emotional, physic, instrumental, material and assistance help offer by people or organizations to have like objective promote student's wellbeing and encourage their academic practicum context adaptation demands.

Studying the conceptual content of the indicators for each dimension and the EFA of each sub-scale helped to observe the presence of two factors in each one of them which coincided with the types of support provided by each one of the sources. The results from the rotations of the elements comprising each one of the EAPAP sub-scales (Appendix C) showed that: in dimension 1, "Academic Institution Support", indicators with greater loading in the first component display conceptual content associated with emotional support, and those for the second factor associated with instrumental support; in dimension 2, "Clinical facilitator Support", the content was linked to appraisal support and emotional support; in dimension 3, "Peers Support", it was linked to information support and emotional support; and in dimension 4, "Preceptor Support", it was linked to appraisal support and information support.

This indicator distribution structure provides information on the support sources and the support type offered by each one of them based on the different sub-scales, divided into four dimensions with two components each which present significant inter-correlations among all of them. The EFA results of the eight dimensions based on the composite scores obtained for their corresponding indicators (Table 2) showed that a grouping in line with the sources that provided each support type was maintained. The set of eight dimensions explain the $86.4 \%$ total variance, considerably improving that obtained in the structure with four first-order dimensions.

The sub-scales displayed internal consistency indices higher than 0.75 , coefficients which are considered adequate bearing in mind the limited number of indicators they comprise.

\section{Confirmatory factor analysis}

In order to confirm the underlying structure, three rival measurement models, plausible from a theoretical and empirical perspective, were evaluated. The results (Table 3 ) suggest that the 2 nd-order model with 4 correlated factors presents more satisfactory goodnessof-fit indices. The Satorra-Bentler Scaled $\chi^{2}$ statistic displayed a value of S-B $\chi^{2}=597.91$ ( $\mathrm{df}=212, P<0.000$ ). The parsimonious fit of the model (normed chi-square $=2.8$ ) was displayed within the levels recommended by Carmines and Mclver (1981). In the fit indices, the Normed Fit Index (NFI) displayed a value of 0.940 , the Non-Formed Fit Index (NNFI) of 0.951 and the Comparative Fit Index (CFI; Bentler, 1990) of 0.960. The Root Mean Square Error Approximation (RMSEA; Hu \& Bentler, 1999) was at 0.051. Conclusions can be drawn that all the calculated goodness-of-fit indices display a positive fit between the hypothesized theoretical model and the data from the sample, therefore it was not possible to prove that the model was incorrect, and it was proven that it is one of the possible acceptable models (Hair, Anderson, Tatham, \& Black, 1999).

In the most thorough analysis of the values which displayed the standardized solution for the proposed model (Fig. 1), it is possible to check that all parameters present positive and significant estimates.
The indicators present adequate reliability, with factorial loadings higher than $0.70, \mathrm{R}^{2}$ higher than 0.50 , and a reliability in each construct comprising values between 0.88 and 0.95 , much higher than the recommended minimum (Hair et al., 1999). With regard to the convergent validity of the constructs, the average variance extracted from the firstorder factors showed values between 0.69 and 0.88 and the loadings presented by the eight first-order factors regarding the four secondorder dimensions are in the range of $\lambda=0.74$ and $\lambda=0.99$. Lastly, it was found that the root of the average variance extracted for each construct presented a value higher than the correlation value that each one had with the rest, which demonstrates discriminant validity (Chin, 1998).

The model was later tried out on a random sample of half of the study's subjects. The goodness-of-fit indices based on the data from this sample (which is outlined in Table 4 together with the data from the full sample) are considered acceptable.

\section{Model invariance}

For the invariance study the multi-sample analyses were conducted based on a random sub-sample made up of 260 students from the 2012/ 13 course cohort and the sample of 260 students from the 2013/14 course cohort, following the proposal of Bollen (1989) which indicates the convenience of analyzing similarly sized samples. The Comparative Fit Index (CFI) is regarded as the main indicator in the assessment of factorial invariance, considering that differences in this index which are higher than 0.01 and more in favor of the less restrictive model would lead to the rejection of the more restrictive model (Chen, 2007; Cheung \& Rensvold, 2002).

The descriptive fit indices obtained were satisfactory (Table 5 displays the indices of the hierarchical set of estimates made), which makes it possible to accept equivalence of the measurement model between groups in the different levels of factorial invariance tested.

As a complement to the measurement invariance, the invariance of the model structure was studied (the distribution and relationship between the latent factors). The estimated fit indices may be considered satisfactory ( $\mathrm{S}-\mathrm{B} \chi^{2}=785,21, \mathrm{df}=432$; CFI $=0.954$; RMSEA $=$ 0.056), therefore it can be concluded that the factor structure presents a high level of invariance in the two samples.

\section{Conclusions}

In this study, the development of an instrument which measures the level of overall academic support perceived by nursing students during the practicum was analyzed, as well as the level of support provided by various sources and the type of support offered by each of them.

The scale displays a high internal consistency (Cronbach's alpha $=$ 0.913 ) and the sub-scales showed reliability coefficients higher than 0.88 . Validation using EFA and CFA techniques helped to confirm the factor structure of the scale and demonstrate its validity and invariance for the two analyzed cohorts of students, considering that the constructs have an equivalent latent structure and their relationships are similar in both groups. The results obtained using CFA help to draw conclusions that the academic support in the practicum construct is made up of four second-order dimensions: "peers", "preceptor", "clinical facilitator" and "academic institution". The EFA and CFA have allowed to observe that these dimensions are defined by first-order factors which correspond with the type of academic support provided by each one of the

Table 4

Fit indices for the full sample analyses $(N=710)$ and the random sample analyses $(N=354)$.

\begin{tabular}{|c|c|c|c|c|c|c|c|}
\hline Model & Satorra-Bentler $\chi 2^{1}$ & df & $\mathrm{S}-\mathrm{B} \chi 2 / \mathrm{gl}$ & NFI Robust & NNFI Robust & CFI Robust & RMSEA Robust \\
\hline Full sample & 597.91 & 212 & 2.8 & 0.940 & 0.952 & 0.960 & $0.051(0.046,0.055)$ \\
\hline Random sample & 451.82 & 212 & 2.1 & 0.914 & 0.943 & 0.952 & $0.057(0.049,0.064)$ \\
\hline
\end{tabular}

$1 p<0.00000$. 
Table 5

Fit indices for invariance tests $(N=710)$.

\begin{tabular}{|c|c|c|c|c|c|c|c|}
\hline Model & Satorra-Bentler $\chi 2^{1}$ & $\mathrm{df}$ & $\Delta \mathrm{S}-\mathrm{B} \chi 2 / \mathrm{gl}$ & $\chi 2 / \mathrm{p}$ & NNFI Robust & CFI Robust & RMSEA Robust \\
\hline Configural invariance & 770.58 & 424 & & & 0.946 & 0.955 & $0.056(0.050,0.062)$ \\
\hline Metric invariance & 781.34 & 439 & $8.63 / 15$ & 0.8962 & 0.949 & 0.955 & $0.055(0.048,0.061)$ \\
\hline Scalar invariance & 827.02 & 454 & $69.95 / 15$ & 0.0000 & 0.946 & 0.954 & $0.056(0.050,0.062)$ \\
\hline Error variance invariance & 849.85 & 484 & $41.17 / 30$ & 0.0841 & 0.948 & 0.955 & $0.054(0.048,0.060)$ \\
\hline
\end{tabular}

${ }^{1} p<0.00000$.

sources within the training context of the practicum. This construct is definitive defined as emotional, physic, instrumental, material and assistance help offer by people or organizations to have like objective promote student's wellbeing and encourage their academic practicum context adaptation demands.

Therefore, insofar as the psychometric characteristics of the Academic Support in the Practicum Scale (EAPAP) are concerned, it was possible to confirm its factor structure via a measurement model which presented satisfactory goodness-of-fit indices. For this reason, it can be stated that the scale helped to evaluate with sufficient reliability and validity the perception of overall academic support in the practicum, the specific type from each one of the sources, and the magnitude of each one of the support types they provide.

In addition, the study shows that the information obtained using the instrument for each one of the support sources is consistent with the role carried out by each of them within the practicum training process. As such, the appraisal support (that which provides the individual with important information for their self-assessment) perceived by the student comes from both the preceptor and clinical facilitator. This concurrence does not occur in the second type of support perceived by students in each one of them, assigning informative support (information to resolve problems or reach goals) to the preceptor, thereby agreeing with Hombrados and Castro (2013) and Browning and Pront (2015), and emotional support (offers the individual empathy, trust and affection) to the clinical facilitator. In both cases, it matches with the role expected of them in the practicum training scope. Regarding peers, the two types of support perceived are informative and emotional, thereby coinciding with studies by Mazer and Thompson (2011a), Thompson and Mazer (2009), Thompson (2008) and Aston and Molassiotis (2003), in which support types are considered as the most substantive in the students' assessment. Regarding support types attributed to Academic Institution, both instrumental support (provision of material or temporary resources or services) and emotional support (personal tutors, practicum coordination, academic coordinators, lecturers, etc.) are set in line with the resources belonging to the academic structures (Braine \& Parnell, 2011; Chan, So, \& Fong, 2009; Price, Hastie, Duffy, Ness, \& McCallum, 2011; Weitzel \& McCahon, 2008).

These results corroborate the usefulness of this tool considering the lack of instruments to evaluate academic support for college students, and its presence in the specific context of the practicum.

As for implications for practice, these findings have implications for institutional policies and practices concerning the implementation of interventions that promote the support provided by specific sources of the practicum. These interventions will have a positive impact in the levels of satisfaction of the students. The evaluation provided by the instrument allows to plan specific actions for each one of the sources of support in the Practicum.

Insofar as limitations of this study are concerned: the study was conducted on an incidental sample, consequently, the findings cannot be generalized. Leading towards new investigations, it would be necessary to check in the future if the scale is used as a valid instrument in research about other degrees which have similar structures in their practicum. Similarly, it would be important to carry out further investigation on the support types which match the sources and their specific features. Lastly, using a broader sample and one which is more representative of other universities in future research would facilitate a solid perspective of the practicum and its idiosyncrasies.

\section{Acknowledgements}

The researchers would like to express their thank to the San Juan de Dios University School of Nursing and Physiotherapy for the funding which supported "Proyecto Hospitare" of which this study is an integral part. This is an interdepartmental project (Department of Health Sciences and Department of Education, Research Methods and Evaluation) which has been recognized as an independent project by the Research Committee of Comillas Pontifical University. We would also like to extend our thanks to the centers, professors and students of the participating universities, who with their support and contribution have made this research possible.

Appendix A. ESCALA DE APOYO ACADÉMICO EN EL PRÁCTICUM (EAPAP) (Spanish version) LE PRESENTAMOS A CONTINUACIÓN UNA SERIE DE CUESTIONES PARA QUE REFLEXIONES SOBRE EL APOYO O LA AYUDA QUE HA PODIDO RECIBIR DURANTE EL ÚLTIMO ROTATORIO DE PRÁCTICAS QUE HAS REALIZADO EN ESTE CURSO.

Valore en una escala de 0 a 10 cada una de las afirmaciones.

\footnotetext{
titulaciones

Durante mi último rotatorio de prácticas otro/s estudiante/s:

1. Me escuchó cuando necesitaba expresar mis frustraciones durante las prácticas

2. Me explicó cómo resolver un problema específico

3. Me enseñó a realizar una intervención

4. Compartió conmigo sus sentimientos ante las prácticas

5. Me aclaró cómo realizar una intervención

6. Me escuchó cuando necesitaba expresar mis frustraciones con el tutor
}

En este apartado va a evaluar el apoyo académico que ha recibido por parte de otro/s estudiante/s, ya fueran de su centro o de otras universidades, o, incluso, de otras 
En este apartado va a evaluar el apoyo académico que ha recibido por parte de su escuela/facultad a través de la planificación y desarrollo del plan de estudios y el acceso a los recursos que le ofrece (biblioteca, tutor de curso, recursos informáticos y bibliográficos, organización, etc.)

La forma en que la Escuela/Facultad ha desarrollado el plan de estudios y ha puesto a mi disposición sus recursos durante mi último rotatorio de prácticas:

7. Me orientó sobre cómo prepararme mejor para las prácticas

8. Me facilitó los recursos bibliográficos que precisaba para la realización de trabajos relacionados con las prácticas

9. Me facilitó ser escuchado cuando necesitaba expresar mis frustraciones durante las prácticas

10. Me facilitó ser escuchado cuando necesitaba expresar mis frustraciones con el tutor de prácticas

11. Me facilitó los recursos bibliográficos que necesitaba para el estudio de contenidos teóricos relacionados con las prácticas

En este apartado va a evaluar el apoyo académico que ha recibido por parte de la enfermera de referencia o tutora profesional/clínica (el/los profesional/es responsable/s de su formación diaria en el servicio hospitalario o del centro de salud donde ha realizado sus prácticas)

Durante mi último rotatorio de prácticas la/s enfermera/s responsable de mi formación en el servicio que me asignaron:

12. Examinó mis intervenciones/actividades y me dio sugerencias

13. Me felicitó por mi trabajo en las prácticas

14. Me explicó alguno de los procedimientos que no entendía.

15. Me dijo que lo estaba haciendo muy bien en prácticas

16. Me aclaró cómo realizar una intervención/actividad

17. Reconoció mi esfuerzo en prácticas

En este apartado va a evaluar el apoyo académico que ha recibido por parte del profesor de la escuela/facultad responsable de tutorizar el seguimiento de su formación práctica (a través del diario reflexivo, el portafolio o los trabajos de campo que ha realizado durante la rotación, visitas periódicas al servicio donde realizó sus prácticas, etc.)

Durante mi último rotatorio de prácticas profesor de la escuela/facultad responsable de tutorizar el seguimiento de mi formación práctica:

18. Incrementó mi confianza durante las prácticas

19. Me hizo sentir mejor durante las prácticas

20. Reconoció mi esfuerzo en prácticas

21. Aumentó mi autoestima con su apoyo

22. Me felicitó por mi trabajo en las prácticas

23. Me dijo que lo estaba haciendo muy bien en prácticas

ACADEMIC SUPPORT IN THE PRACTICUM SCALE (EAPAP) (English version). BELOW YOU WILL FIND A SERIES OF QUESTIONS FOR YOU TO REFLECT ON THE SUPPORT OR ASSISTANCE THAT YOU WERE ABLE TO RECEIVE DURING THE LAST PLACEMENT ROTATION THAT YOU COMPLETED IN THIS ACADEMIC YEAR.

Give a score on a scale of 0 to 10 for each one of the statements.

This section will evaluate the academic support received from other students, whether they are from your school or other universities, or even on other degree courses.

During my last placement rotation other students:

1. Listened to me when I needed to voice my frustrations during the placement

2. Explained to me how to resolve a specific problem

3. Taught me how to carry out a procedure

4. Shared their feelings about the placement with me

5. Clarified how to carry out a procedure

6. Listened to me when I needed to voice my frustrations with the tutor

This section will evaluate the academic support received from your school/Academic Institution via planning and developing the study plan and the access to resources on offer (library, course tutor, IT and bibliographic resources, organization, etc.)

The way in which the School/Academic Institution developed the study plan and made their resources available to me during my last placement rotation:

7. Guided me on how to prepare myself better for the placement

8. Provided me with bibliographic resources which was essential to complete work related to the placement

9. Helped me to be heard when I needed to voice my frustrations during the placement

10. Helped me to be heard when I needed to voice my frustrations with the placement tutor

11. Provided me with bibliographic resources that I needed to study theoretical material related to the placement

This section will evaluate the academic support received from the Preceptor (the professional(s) in charge of your daily training in the hospital service or responsible for the health center where you carried out your placement)

During my last placement rotation the Preceptor was in charge of my training in the service:

12. Studied my procedures/activities and gave me suggestions

13. Praised me for my work in the placement

14. Explained procedures that I did not understand

15. Told me that I was doing well during my placement

16. Clarified how to carry out a procedure/activity

17. Recognized my effort during the placement

This section will evaluate the academic support received from Clinical Facilitator who was responsible for overseeing the follow-up of your practical training (by means of the daily reflection, portfolio or field work you completed during your rotation, regular visits to the service where you completed your placement, etc.) During my last placement rotation the Clinical Facilitator who was responsible for overseeing the follow-up of my practical training:

18. Boosted my confidence during the placement

19. Made me feel better during the placement

20. Recognized my effort during the placement

21. Enhanced my self-esteem with his/her support

22. Praised me for my work in the placement

23. Told me that I was doing well during my placement 
Appendix B. Factor loading of each item of Academic Support in the Prácticum Scale (EAPAP). Configuration matrix. Variance explained and Cronbach's $\alpha(N=710)$.

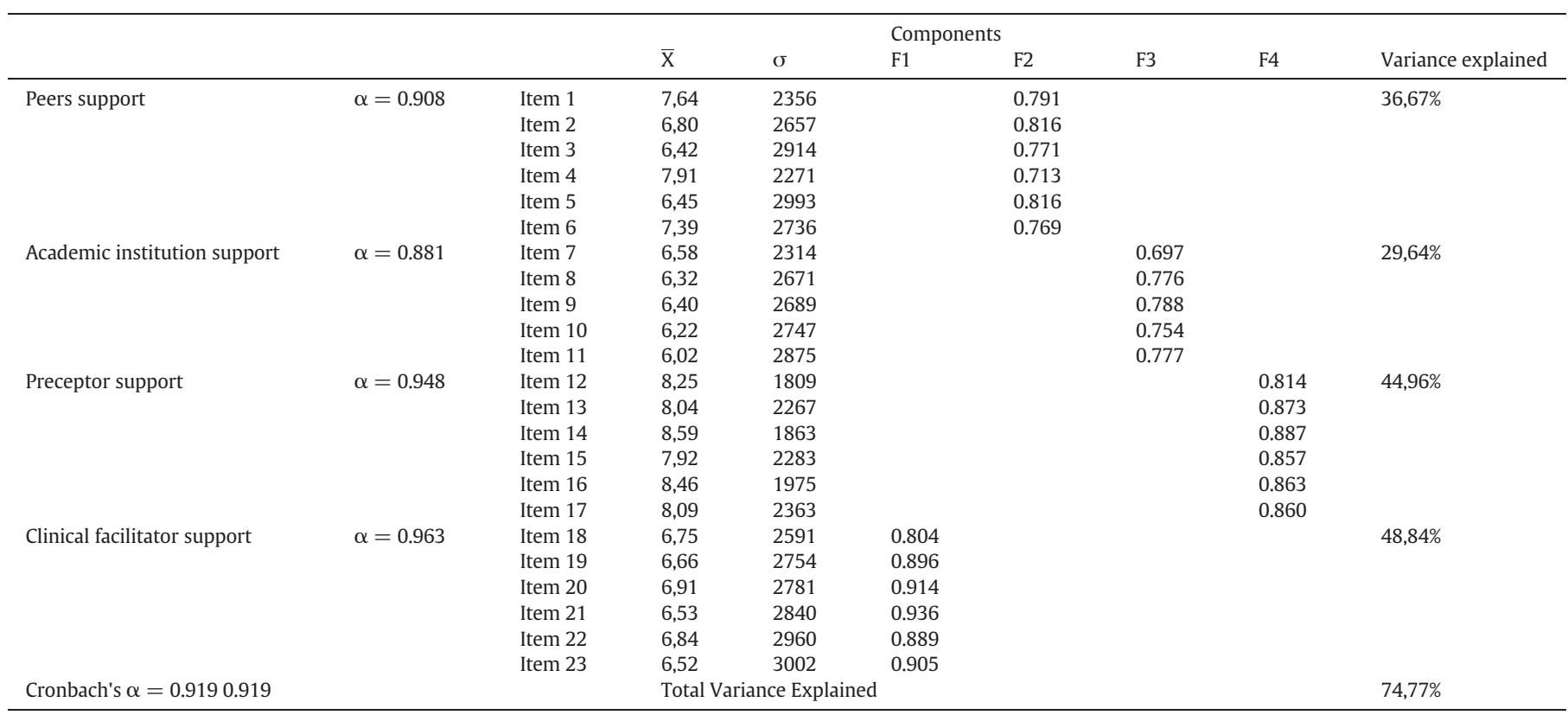

Extraction Method: Unweighted Least Squares. Dispersion matrix: Polychoric Correlations.

Rotation Method: Promax.

Appendix C. Mean, SD and loading factor of each item on the subscales of the Academic Support in the Prácticum Scale (EAPAP). Variance explained and Cronbach's $\alpha(N=710)$.

\begin{tabular}{|c|c|c|c|c|c|c|c|}
\hline \multirow[t]{8}{*}{ Subscale 1} & PEERS SUPPORT & & & COMPONENTS & & $\alpha$ & Variance explained \\
\hline & Item number & M & $\sigma$ & Information Support & Emotional support & & \\
\hline & Item 3. & 6,42 & 2,91 & 1012 & & $\alpha=0.90$ & $83,804 \%$ \\
\hline & Item 5. & 6,45 & 2,99 & ,964 & & & \\
\hline & Item 2. & 6,80 & 2,66 &, 751 & & & \\
\hline & Item 4. & 7,91 & 2,27 & & ,936 & & \\
\hline & Item 1. & 7,64 & 2,36 & & 870 & & \\
\hline & Item 6. & 7,39 & 2,74 & & ,845 & & \\
\hline \multirow[t]{7}{*}{ Subscale 2} & ACADEMIC INSTITUTION SUPPORT & & & COMPONENTS & & $\alpha$ & Variance explained \\
\hline & Item number & M & $\sigma$ & Emotional Support & Instrumental support & & \\
\hline & Item 10. & 6,22 & 2,75 & 981 & & $\alpha=0.88$ & $84,180 \%$ \\
\hline & Item 9. & 6,40 & 2,69 & ,952 & & & \\
\hline & Item 7. & 6,58 & 2,31 &, 587 & ,318 & & \\
\hline & Item 11. & 6,02 & 2,87 & & ,958 & & \\
\hline & Item 8. & 6,32 & 2,67 & & ,929 & & \\
\hline \multirow[t]{8}{*}{ Subscale 3} & PRECEPTOR SUPPORT & & & COMPONENTS & & $\alpha$ & Variance explained \\
\hline & Item number & M & $\sigma$ & Appraisal Support & Information support & & \\
\hline & Item 17. & 8,09 & 2,36 & ,929 & & $\alpha=0.94$ & $87,649 \%$ \\
\hline & Item 13. & 8,04 & 2,27 & 914 & & & \\
\hline & Item 15. & 7,92 & 2,28 & 897 & & & \\
\hline & Item 16. & 8,46 & 1,97 & & ,926 & & \\
\hline & Item 12. & 8,25 & 1,81 & &, 881 & & \\
\hline & Item 14. & 8,59 & 1,86 & &, 878 & & \\
\hline \multirow[t]{8}{*}{ Subscale 4} & CLINICAL FACILITATOR SUPPORT & & & COMPONENTS & & $\alpha$ & Variance explained \\
\hline & Item number & M & $\sigma$ & Emotional Support & Appraisal support & & \\
\hline & Item 18. & 6,75 & 2,59 & 1009 & & $\alpha=0.96$ & $92,739 \%$ \\
\hline & Item 19. & 6,66 & 2,75 & ,905 & & & \\
\hline & Item 21. & 6,53 & 2,84 &, 725 & & & \\
\hline & Item 22. & 6,84 & 2,96 & & ,985 & & \\
\hline & Item 23. & 6,52 & 3,00 & & ,943 & & \\
\hline & Item 20. & 6,91 & 2,78 & ,388 & ,604 & & \\
\hline
\end{tabular}

Extraction Method: Principal Component Analysis. Rotation Method: Promax with Kaiser Normalization.

a. Rotation converged in 3 iterations. 


\section{References}

Andrews, G. J., Brodie, D. A., Andrews, J. P., Hillan, E., Thomas, B. G., Wong, J., \& Rixon, L (2006). Professional roles and communications in clinical placements: A qualitative study of nursing students' perceptions and some models for practice. International Journal of Nursing Studies, 43, 861-874. http://dx.doi.org/10.1016/j.ijnurstu.2005.11. 008.

Arribas, J. (2013). Hacia un modelo causal de las dimensiones del estrés académico en estudiantes de enfermería. Revista de Educación, 360, 533-556. http://dx.doi.org/10. 4438/1988-592X-RE-2011-360-126.

Aston, L., \& Molassiotis, A. (2003). Supervising and supporting student nurses in clinical placements: The peer support initiative. Nurse Education Today, 23(3), 202-210. http://dx.doi.org/10.1016/S0260-6917(02)00215-0.

Batista-Foguet, J. M., Saris, W., Boyatzis, R., Guillén, L., \& Serlavós, R. (2009). Effect of response scale on assessment of emotional intelligence competencies. Personality and Individual Differences, 46(5-6), 575-580. http://dx.doi.org/10.1016/j.paid.2008.12. 011.

Bentler, P. (1990). Comparative fit indices in structural equation models. Psychological Bulletin, 107, 238-246.

Bentler, P. (2006). EQS 6.1 Structural equations program manual. Encino, CA: Multivariate Software, Inc.

Bentler, P. M., \& Wu, E. J. C. (2012). EQS 6.2 for Windows. Encino CA: Multivariate Software, Inc.

Bollen, K. (1989). Structural equations with latent variables. New York: Wiley.

Braine, M., \& Parnell, J. (2011). Exploring student's perceptions and experience of personal tutors. Nurse Education Today, 31(8), 904-910. http://dx.doi.org/10.1016/j.nedt. 2011.01.005.

Browning, M., \& Pront, L. (2015). Supporting nursing student supervision: An assessment of an innovative approach to supervisor support. Nurse Education Today, 35(6), 740-745. http://dx.doi.org/10.1016/j.nedt.2015.02.003.

Carmines, E. \& McIver, J. (1981). Analyzing models with unobserved variables: Analisys of covariance structures. In G. W. Boornstedt, \& E. F. Borgatta (Eds.), Social measure ment: Current issues (pp. 65-115). Beverly Hills: Sage.

Chan, K. L., So, W. K., \& Fong, Y. T. (2009). Hong Kong baccalaureate nursing Students' stress and their coping strategies in clinical practice. Journal of Professional Nursing 25(5), 307-313. http://dx.doi.org/10.1016/j.profnurs.2009.01.018.

Chen, F. (2007). Sensitivity of goodness of fit indexes to lack of measurement invariance. Structural Equation Modeling, 14(3), 464-504. http://dx.doi.org/10.1080/ 10705510701301834

Cheung, G., \& Rensvold, R. (2002). Evaluating goodness-of-fit indexes for testing measurement invariance. Structural Equation Modeling, 9, 233-255. http://dx.doi.org/10. 1207/S15328007SEM0902 5.

Chin, W. (1998). Issues and opinion on structural equation modeling. MIS Quarterly, 22(1), 7-16.

Eick, S. A., Williamson, G. R., \& Heath, V. (2012). A systematic review of placement-related attrition in nurse education. International Journal of Nursing Studies, 49, 1299-1309. http://dx.doi.org/10.1016/j.ijnurstu.2011.12.004.

Flora, D., \& Curran, P. (2004). An empirical methods of estimation for confirmatory factor analysis with ordinal data. Psychological Methods, 9(4), 466-491. http://dx.doi.org/10. 1037/1082-989X.9.4.466.

González, X. A., \& Hevia, I. (2011). El Practicum de la Licenciatura de Pedagogía: estudio empírico desde la perspectiva del alumnado. Revista de Educación, 354, 209-236.

Gottlieb, B. (1981). Social networks and social support in community mental health. In B. H. Gottlieb (Ed.), Social networks and social support (pp. 11-42). Londres: Sage.

Graham, M. M., Lindo, J., Bryan, V. D., \& Weaver, S. (2016). Factors associated with stress among second year student nurses during clinical training in jamaica. Journal of Professional Nursing, 32(5), 383-391. http://dx.doi.org/10.1016/j.profnurs.2016.01. 004.

Hair, J., Anderson, R., Tatham, R., \& Black, W. (1999). Análisis multivariante. Madrid: Pearson Education/Prentice Hall.

Helminen, K., Coco, K., Johnson, M., Turunen, H., \& Tossavainen, K. (2016). Summative assessment of clinical practice of student nurses: A review of the literature. International Journal of Nursing Studies, 53, 308-319. http://dx.doi.org/10.1016/j. ijnurstu.2015.09.014

Hombrados, I., \& Castro, M. (2013). Apoyo social, clima social y percepción de conflictos en un contexto educativo intercultural. Anales de Psicología, 29(1), 108-122. http:// dx.doi.org/10.6018/analesps.29.1.123311.

House, J. S. (1981). Work stress and social support. Reading, Massachusetts: Addison-Wesley Publishing Company.

Hu, L., \& Bentler, P. (1999). Cut-off criterion for fit indexes in covariance structure analysis: Conventional criteria versus new alternatives. Structural Equation Modeling, 6 1-55. http://dx.doi.org/10.1080/10705519909540118.

IBM Corporation (2011). IBM SPSS Statistics for Windows, version 20.0 NY: Armonk

Jones, A. (2008). The effects of out-of-class support on student satisfaction and motivation to learn. Communication Education, 57, 373-388. http://dx.doi.org/10.1080/ 03634520801968830
Lin, N., Dean, A., \& Ensel, W. (Eds.). (1986). Social support, life events and depression. Nueva York: Academic Press.

Lorenzo-Seva, U., \& Ferrando, P. (2013). FACTOR 9.2: A comprehensive program for fitting exploratory and semiconfirmatory factor analysis and IRT model. Applied Psychological Measurement, 37(6), 497-498. http://dx.doi.org/10.1177/ 0146621613487794

Malecki, C., Demaray, M., \& Elliott, S. (2000). The child and adolescent social support scale. DeKalb (USA): Northern Illinois University.

Martínez, E., \& Raposo, M. (2011). Funciones generales de la tutoría en el Practicum: entre la realidad y el deseo en el desempeño de la acción tutorial. Revista de Educación, 354, $155-181$.

Mazer, J., \& Thompson, B. (2011a). Student academic support: A validity test. Communication Research Reports, 28(3), 214-224. http://dx.doi.org/10.1080/ 08824096.2011 .586074$.

Mazer, J. P., \& Thompson, B. (2011b). The validity of the student academic support scale: Associations with social support and relational closeness. Communication Reports, 24(2), 74-85. http://dx.doi.org/10.1080/08934215.2011.622237.

O'Rourke, J., \& Houghton, S. (2006). Students with mild disabilities in regular classrooms: The development and utility of the student perceptions of classroom support scale. Journal of Intellectual and Developmental Disability, 31(4), 232-242. http://dx.doi. org/10.1080/13668250601050310.

Peterson, J. Peterson, N., Lowe, J. \& Nothwehr, F. (2009). Promoting leisure physical activity participation among adults with intellectual disabilities: Validation of self-efficacy and social support scales. Journal of Applied Research in Intellectual Disabilities, 22(5), 487-497. http://dx.doi.org/10.1111/j.1468-3148.2009.00500.x.

Price, L., Hastie, L., Duffy, K., Ness, V., \& McCallum, J. (2011). Supporting students in clinical practice: Pre-registration nursing students' views on the role of the lecturer. Nurse Education Today, 31(8), 780-784. http://dx.doi.org/10.1016/j.nedt.2011.04.009.

Rodicio, M. L., \& Iglesias, M. (2011). La formación en competencias a través del Practicum: un estudio piloto. Revista de Educación, 354, 99-124.

Savitz-Romer, M. (2009). Removing roadblocks to rigor: Linking academic and social supports to ensure college readiness and success. Pathways to college network Retrieved from https://eric.ed.gov/?id=ED509545

Song, J., Bong, M., Lee, K., \& Kim, S. (2015). Longitudinal investigation into the role of perceived social support in adolescents' academic motivation and achievement. Journal of Educational Psychology, 107(3), 821-841. http://dx.doi.org/10.1037/edu0000016.

Tang, W., Cui, Y., \& Babenko, O. (2014). Internal consistency: Do we really know what it is and how to assess it? Journal of Psychology and Behavioral Science, 2(2), 205-220 Retrieved from http://jpbsnet.com/journals/jpbs/Vol_2_No_2_June_2014/13.pdf

Tao, S., Dong, Q., Pratt, W., Hunsberger, B., \& Pancer, S. M. (2000). Social support: Relations to coping and adjustment during the transition to University in the People's Republic of China. Journal of Adolescent Research, 15(1), 123-144. http://dx.doi.org/10.1177/ 0743558400151007.

Thompson, B. (2008). How college freshmen communicate student academic support: A grounded theory study. Communication Education, 57, 123-144. http://dx.doi.org/10. $1080 / 03634520701576147$.

Thompson, B., \& Mazer, J. (2009). College student ratings of student academic support: Frequency, importance, and modes of communication. Communication Education, 58(3), 433-458. http://dx.doi.org/10.1080/03634520902930440.

Turkpour, A., \& Mehdinezhad, V. (2016). Social and academic support and adaptation to college: Exploring the relationships between indicators' college students. International Education Studies, 9(12), 53. http://dx.doi.org/10.5539/ies.v9n12p53.

Ujváriné, A. S., Zrínyi, M., Tóth, H., Zékanyné, R. I., Szögedi, I., \& Betlehem, J. (2011). The role of faculty and clinical practice in predicting why nurses graduate in Hungary. Nurse Education Today, 31(1), 94-101. http://dx.doi.org/10.1016/j.nedt.2010.04.003.

Weitzel, M., \& McCahon, C. (2008). Stressors and supports for baccalaureate nursing students completing an accelerated program. Journal of Professional Nursing, 24(2), 85-89. http://dx.doi.org/10.1016/j.profnurs.2007.06.017.

Wilkes, M., \& Feldman, M. D. (2017). Mentoring clinical trainees: A need for high touch. The Lancet, 389(10065), 135-137. http://dx.doi.org/10.1016/S0140-6736(16)32571-

Wong, D., \& Kwok, S. (1997). Difficulties and patterns of social support of mature college students in Hong Kong: Implications for student guidance and counselling services. British Journal of Guidance and Counselling, 25(3), 377-387. http://dx.doi.org/10. 1080/03069889708253815.

Zabalza, M. (2006). El practicum y la formación del profesorado: balance y propuesta para las nuevas titulaciones. In J. M. Escudero, \& A. Luis (Eds.), La formación del profesorado y la mejora de la educación (pp. 309-330). Barcelona: Octaedro.

Zabalza, M. (2011). El practicum en la formación universitaria: estado de la cuestión. Revista de Educación, 354, 21-43.

Zimet, G., Dahlem, N., Zimet, S., \& Farley, G. (1988). The multidimensional scale of perceived social support. Journal of Personality Assessment, 52, 30-41. http://dx.doi.org/ 10.1207/s15327752jpa5201_2. 